\title{
Erratum to: A bulk mass flux convection scheme for climate model: description and moisture sensitivity
}

\author{
Daehyun Kim • In-Sik Kang
}

Published online: 18 March 2011

(C) Springer-Verlag 2011

\section{Erratum to: Clim Dyn}

DOI 10.1007/s00382-010-0972-2

The original publication of the paper 10.1007/s00382010-0972-2 did not include the acknowledgement section. The authors would like to add the acknowledgement as given below:

Acknowledgments ISK was supported by the National Research Foundation of Korea (NRF) Grant Funded by the Korean Government (MEST) (NRF-2009-C1AAA0012009-0093042) and second phase of the Brain Korea 21.

The online version of the original article can be found under doi:10.1007/s00382-010-0972-2.

D. Kim · I.-S. Kang ( $\bowtie)$

School of Earth and Environmental Sciences,

Seoul National University, Seoul 151-747, South Korea

e-mail: kang@climate.snu.ac.kr

Present Address:

D. Kim

Lamont-Doherty Earth Observatory of Columbia University,

Palisades, NY 10964-1000, USA

e-mail:dkim@ldeo.columbia.edu 